\title{
Eleven years of recovery dynamic after experimental burning and cutting in two Cistus communities
}

\author{
Reyes Tárrega*, Estanislao Luis-Calabuig, Luz Valbuena \\ Area de Ecología, Facultad de Biología, Universidad de León, 24071 León, Spain
}

Received 23 March 2000; revised 1 February 2001; accepted 12 September 2001

\begin{abstract}
Recovery after cutting and burning in two series of experimental shrubland plots dominated by Cistus laurifolius and Cistus ladanifer, respectively, was studied over 11 years. The two communities tend to recover by an autosuccession process after disturbances, with Cistus species being dominant from the first or second year. The greatest diversity is recorded in the first few years after the disturbances, with higher species richness, basically herbaceous ones, and lower dominance effect. Cover by woody species tends to increase but from the fourth year the differences are not significant. The highest herbaceous cover is after one year and the peak is more marked in the cut plots. Herbaceous species cover decreases afterwards and there are small changes in the different years but without clear trends. When all the samplings are compared by a TWINSPAN, the first division separates both communities and the second division the initial and the final phases from each community. The separation between cut and burnt plots is only observed in the final phases. () 2001 Éditions scientifiques et médicales Elsevier SAS
\end{abstract}

Cistus laurifolius / Cistus ladanifer / experimental treatments / recovery / autosuccession

\section{INTRODUCTION}

The Mediterranean ecosystems, as they exist at present, are a result of human activity to a great extent $8,23,31$. Different using methods have produced a mosaic of ecosystems with differing degrees of maturity forming heterogeneous landscapes which guarantee diversity maintenance in the Mediterranean Basin and. in general, in all the Mediterranean climate areas [6. 14, 25]. Most of these ecosystems show great resilience to disturbances $[9]$ and usually recover by an autosuccession process [12]. Most of these species regenerate by vegetative resprout but some, like the Cistus species, are considered obligate seeders, with seeds whose germination is stimulated by heat $[15.16$ $32,36]$ so they spread as a result of fires. Therefore, although most of the species that appear after the regressive impact are the same as those previously occupying the area $[1,4,11,18,21,30,34]$, different disturbances could determine differences in recovery dynamic (both speed of recovery or community spe-

* Correspondence and reprints.

E-mail address: deglcg@unileon.es (R. Tárrega). cies composition), depending on the adaptative traits of the different species.

Shrub communities have been spreading in Spain and other parts of Europe in the last few decades as a result of, on the one hand, secondary succession after pasture and croplands have been abandoned and, on the other, of the superposition of regressive impacts on forest ecosystems [17,29]. Periodic burning is one of the common management methods used by shepherds to halt the proliferation of woody species and maintain pasturage. This practice continues in some areas at present in spite of the decrease in livestock and the lack of later use. Cutting the woody biomass back or down to eliminate shrubs is one of the alternatives encouraged by managers. Various studies have been carried out comparing recovery after burning and cutting in Mediterranean-type ecosystems $[2,3,10$, 18,22], but the regeneration responses do not coincide completely and demonstrate the need to do studies on each specific ecosystem.

The aim of this study is to analyse recovery dynamic after these two experimental disturbances: burning and cutting, on two very similar and close shru 
blands, each dominated by a different species of Cistus: Cistus ladanifer and Cistus laurifolius. Previous studies analysed the recovery dynamic in the first 5 years $[27,28]$. We have now attempted to establish whether stability has been attained in 11 years and whether there are common tendencies or differences as regards species and/or disturbance. Knowledge of recovery dynamic in the short and medium term are basic to community management, whether one wishes to preserve them, or favour progress towards more mature stages (forest) or maintain the initial stages with a view to preserving the diversity of Mediterranean ecosystems.

\section{MATERIAL AND METHODS}

A shrub area situated in the Southwest of the province of León (NW Spain), U.T.M. co-ordinates 29TQG3929, at an altitude of about $900 \mathrm{~m}$, was chosen for the study. Two Cistus communities situated very close to each other $(1 \mathrm{~km})$ and of similar characteristics, but with a different dominant species in each, were chosen. The first was dominated by Cistus ladanifer and the second by Cistus laurifolius with mean covers higher than $70 \%$. The other woody species that appeared, Lavandula stoechas, Halimium umbellatum, Chamaespartium tridentatum and Adenocarpus complicatus, were much less abundant. Herbaceous species were scarce with cover almost always below 2\%. Both Cistus communities had a very homogeneous structure, the Cistus plants being more than 15 years old. They were secondary stages started as a consequence of old fields or pastures being given up. The mature stage in this area is a Quercus pyrenaica - Quercus ilex forest. The climate in the area, according to the Papadakis classification, is cool temperate Mediterranean [20], mean annual rainfall is $469.8 \mathrm{~mm}$, the dry period is in July and August and the definite or probable frost is between October and May. The soil is formed on Silurian materials [19].

Two plots measuring $10 \times 10 \mathrm{~m}$ and separated by a $2 \mathrm{~m}$ wide strip were established in each community, and the same experimental treatments were carried out on each in July 1989. All the woody species were cut down close to ground level in one plot, using a mechanical undergrowth cutter. The second plot was burnt, by simulating a wildfire.

To record changes in the plant community 5 quadrats measuring $1 \mathrm{~m}^{2}$ each, which were randomly chosen in the first sampling and marked for study in subsequent checks, were established. Annual samplings were carried out in the month of June from 1990 to 2000, quantifying all the species present in terms of visually estimated cover percentage. To compare with the surrounding untreated shrubland (control), 5 additional quadrats were also sampled near the experimental plots in each community, in June 2000. Before the experimental disturbances, a sampling had been carried out to establish initial conditions, but herbaceous species were considered jointly because of their low cover (table . Plant nomenclature is according to Tutin et al. [35].

Diversity was calculated as species richness, distinguishing between herbaceous and woody species. Cover values (after arc-sine transformation) and richness values were compared using analysis of variance. In order to compare changes in time in the same plot a repeated measures analysis of variance was used. The last samplings (June 2000) were compared by a two-factor analysis of variance, factor $1=$ treatment (burnt plot, cut plot, un-treated plot), factor $2=$ community (Cistus ladanifer community and Cistus lauri

Table I. Cover values of woody species and total cover by herbaceous species in the initial (pre-disturbance) situation (mean of the 5 quadrats of each plot).

\begin{tabular}{|c|c|c|c|c|}
\hline & \multicolumn{2}{|c|}{ Cistus ladanifer Community } & \multicolumn{2}{|c|}{ Cistus laurifolius Community } \\
\hline & Cut Plot & Burnt Plot & Cut Plot & Burnt Plot \\
\hline Cistus ladanifer & 66.0 & 78.0 & 2.0 & \\
\hline Cistus laurifolius & & & 71.0 & 92.0 \\
\hline Halimium umbellatum & 4.2 & 6.2 & 7.2 & \\
\hline Lavandula stoechas & 20.2 & 2.0 & & \\
\hline Rosa sp. & 1.0 & & & \\
\hline Chamaespartium tridentatum & & & 1.2 & 0.2 \\
\hline Adenocarpus complicatus & & & & 0.6 \\
\hline Herbaceous spp. & 0.4 & 4.0 & 1.6 & 0.6 \\
\hline
\end{tabular}


folius community). The Scheffe test [26] was applied for a comparison between pairs when ANOVA was significant $(p<0.05)$. Sample normality had been checked beforehand using the David test [7] and homogeneity of variances with the Cochran test [5]

In order to compare species composition in all the plots a TWINSPAN (two-way indicator species analysis) was used. TWINSPAN is a method of divisive hierarchical classification which carries out a simultaneous classification of samples and species [13]. In this analysis, the mean of the five quadrats of each plot and sampling period was considered.
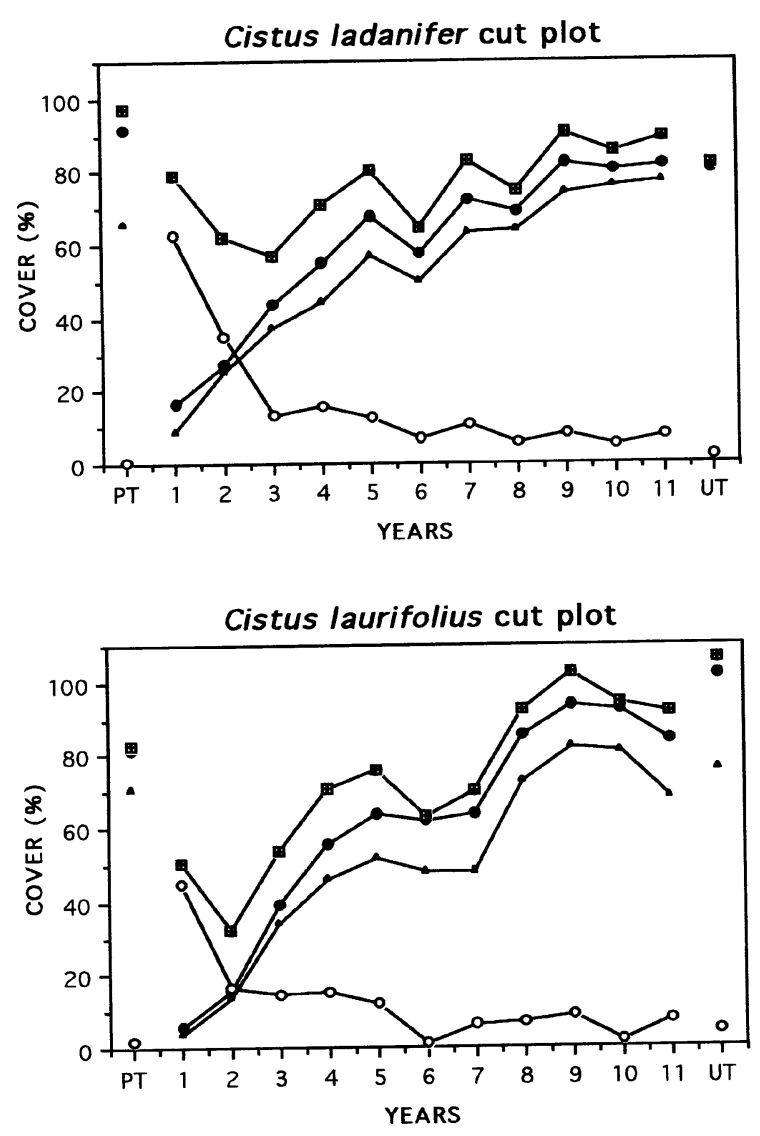

\section{RESULTS}

If the changes in herbaceous and woody cover are observed, an increase in herbaceous species in comparison with the initial situation can be appreciated with greater cover one year after the disturbances (figure - 1). It is more marked in the cut plots than in the burnt ones, with statistical significant differences between both treatments. Herbaceous species cover has little changes without clear temporal trends from the third year. Significant differences between treated and un-treated plots can be detected eleven years after treatments, with less cover in un-treated plot. How
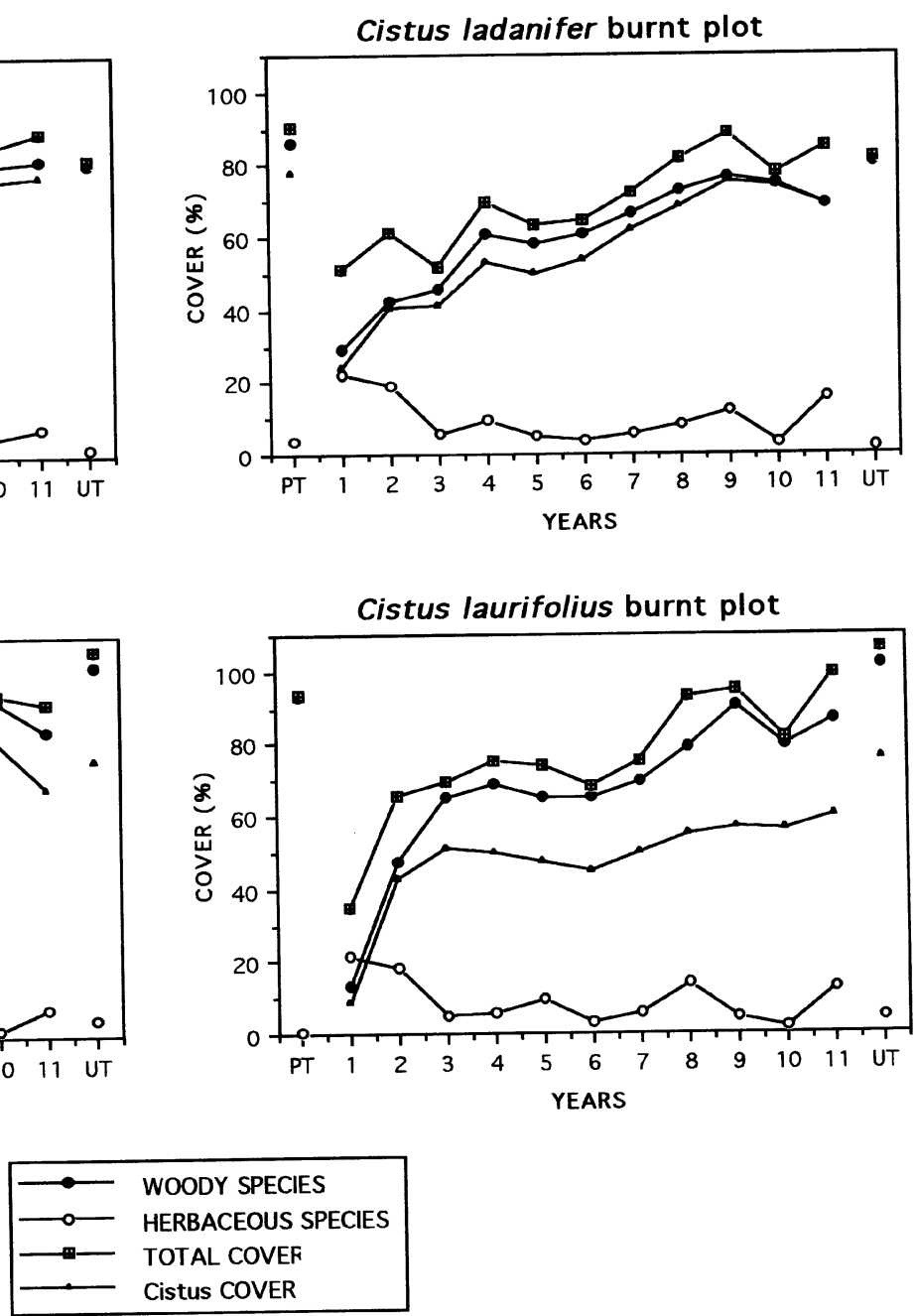

Figure 1. Changes in cover values of each Cistus species, woody and herbaceous species and total cover in the successive years after disturbances in the experimental plots. $(\mathrm{PT}=$ pre-treatment situation, $\mathrm{UT}=$ un-treated plot $)$. 
ever, there are no significant differences between the cut and the burnt plots or between the two communities. Woody cover recovers fast, without significant differences from the fourth year when comparing the values from each plot by repeated measures ANOVA. Statistical differences among treatments are detected when comparing woody cover in the last sampling, but differences cannot be detected by Scheffe test in the comparisons between pairs of plots in the same community (cut, burnt and untreated plot). However, woody species cover is significantly higher in the community dominated by Cistus laurifolius than in the Cistus ladanifer one, also in the untreated plots.

If the cover of both Cistus species is compared with total cover, its clear dominance in the initial situation
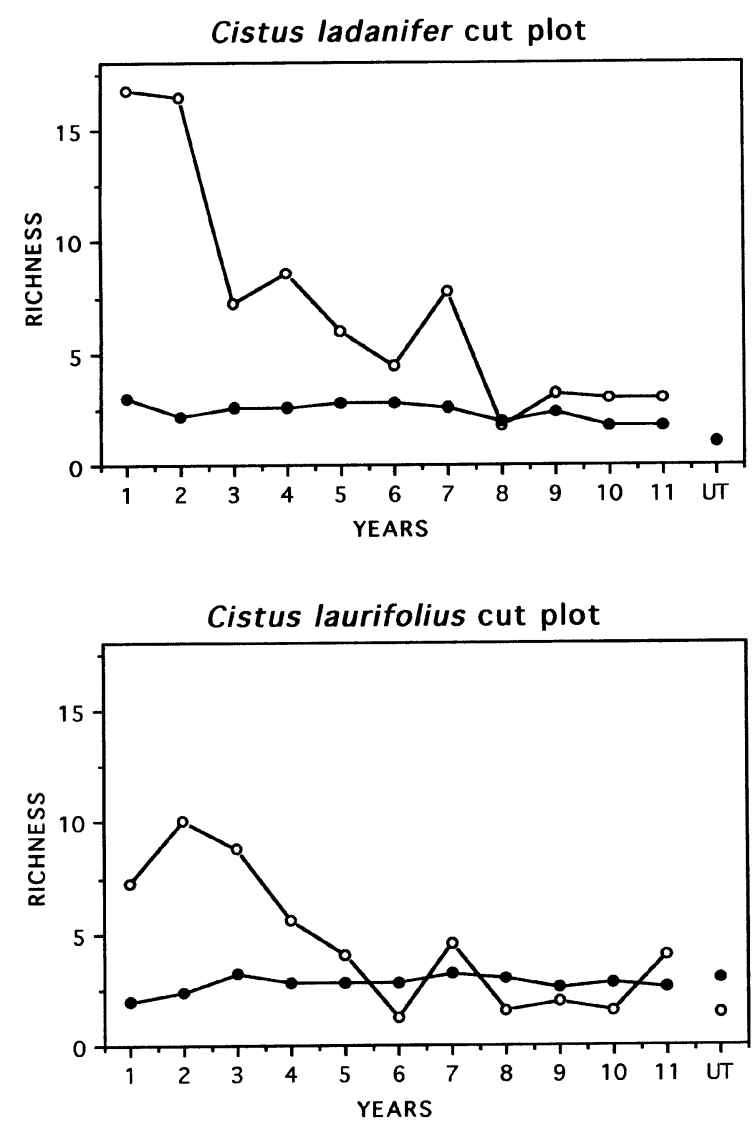

can be seen (foure - 1 ). Cistus recovery is quite fast in all the plots and faster in the burnt ones than the cut ones in the first years. In all the plots it is the dominant species from the second year, and its cover values are similar to those before the disturbances after 7 or 8 years, except in the burnt Cistus laurifolius plot. Differences cannot be detected in the repeated measures ANOVA comparing successive samplings in each plot from the 4th year after treatments. Moreover, there are no significant differences among treatments (cut, burnt and untreated plots) or between species (Cistus ladanifer y Cistus laurifolius) when comparing Cistus cover in the last sampling.

Greatest species richness was observed in the first two years after the disturbances (figure 2). Later the
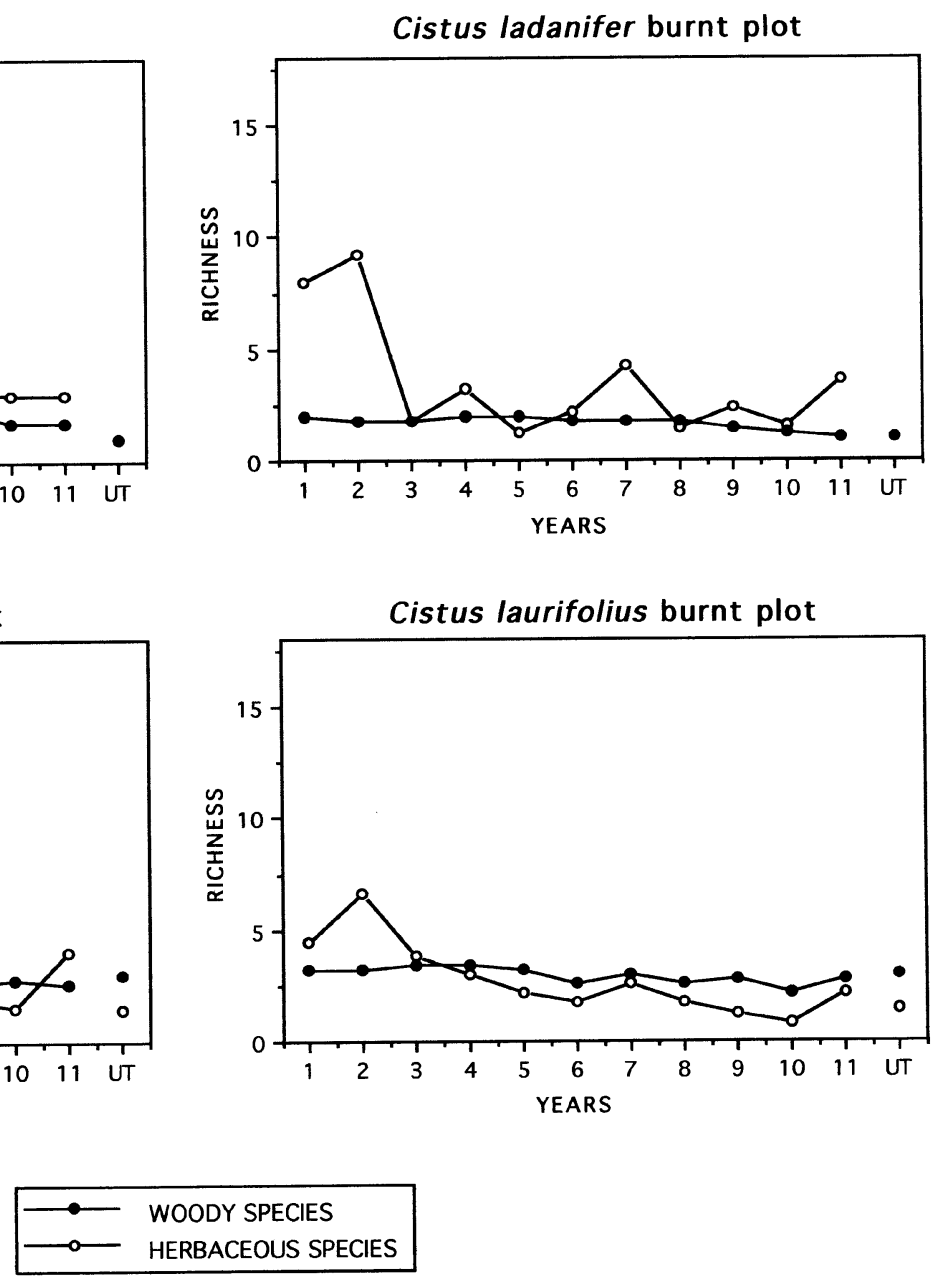

Figure 2. Changes in number of woody and herbaceous species (richness $/ \mathrm{m}^{2}=$ mean values of the five quadrats in each plot and sampling period) in the successive years after disturbances in the experimental plots. (UT $=$ un-treated plot). 
number of species tends to decrease, although there were oscillations in some cases associated with the specific conditions each year, as these are almost always common to the 4 plots (e.g., the rise in year 7, 1996). These variations are basically due to the herbaceous species, as the number of woody ones remains almost constant. There are significant differences in the richness of herbaceous species in the successive years, when comparing by repeated measures ANOVA, but not in the richness of woody species, and this is observed in the four experimental plots. The lower richness of the woody species is seen in the burnt Cistus ladanifer plot where only two species were recorded in most years: Cistus ladanifer and Halimium umbellatum. The highest richness of woody species in the Cistus laurifolius community is also observed in the untreated plots. Therefore, eleven years after treatments there are significant differences between communities, but not among treatments in each community. The opposite is observed for herbaceous richness values; there are not significant differ- ences between communities but there are between treatments, with the lowest herbaceous richness in the un-treated plots.

The separation of both communities can be observed in the first level of division in the sample dendrogram of TWINSPAN (figure 3). The most constant species in both communities during all the study period are Cistus ladanifer, the dominant species in one of the communities, but also present in the other, Halimium umbellatum, Vicia sativa subsp. nigra, Sanguisorba minor and Lotus corniculatus. Cistus laurifolius community are also associated to other woody and herbaceous species. The species characterising the Cistus ladanifer community are mostly herbaceous species which do not appear or they are not so constant in the other community. On a second level, the separation in the sample dendrogram is by time since treatments. The initial phases are associated to herbaceous species, which are present in both communities in the first years, but they do not usually appear

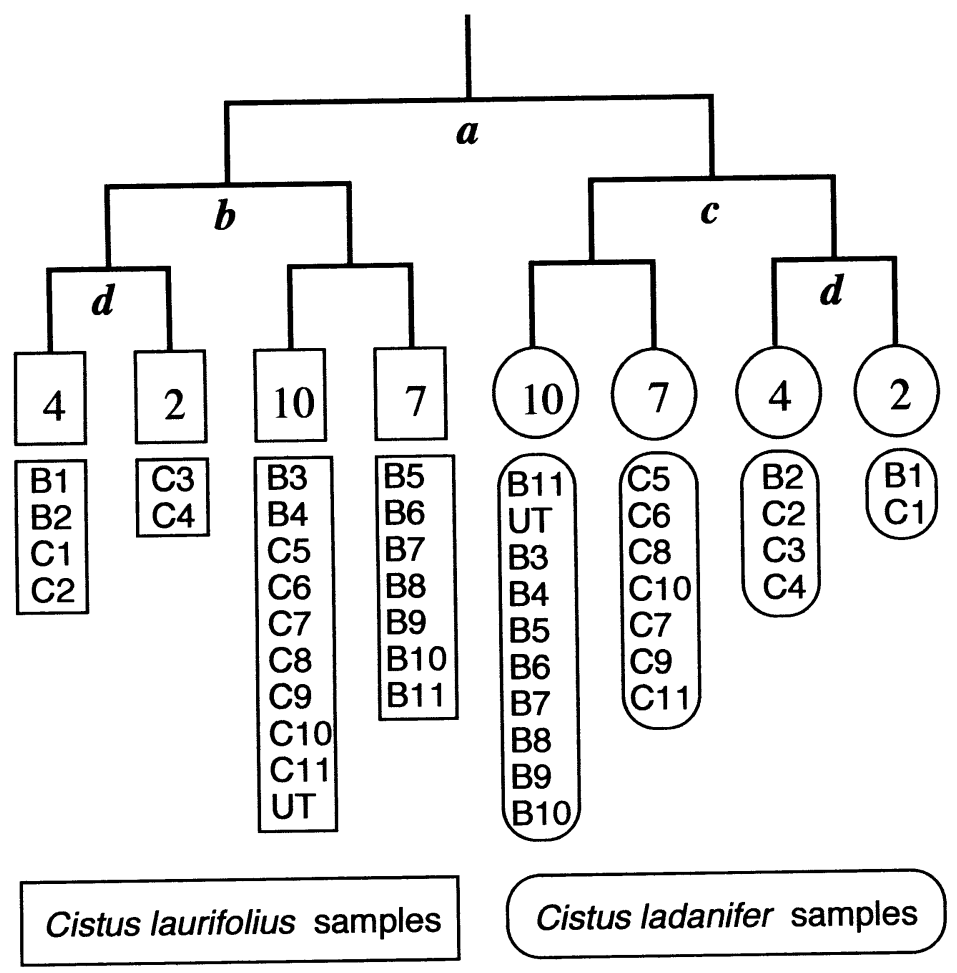

\author{
Preferential spp. \\ a Cistus ladanifer \\ Vicia sativa subsp. nigra \\ Sanguisorba minor \\ Lotus corniculatus \\ Halimium umbellatum \\ b Cistus laurifolius \\ Chamaespartium tridentatum \\ Lathyrus niger \\ Arenaria montana \\ Veronica verna \\ Rubus ulmifolius \\ Adenocarpus complicatus \\ c Vulpia bromoides \\ Logfia minima \\ Arnoseris minima \\ Andryala integrifolia \\ Agrostis capillaris \\ Hypericum perforatum \\ Hieracium pilosella \\ Agrostis capillaris \\ d Sonchus sp. \\ Jasione montana \\ Carlina sp. \\ Aphanes arvensis \\ Aira caryophyllea \\ Teesdalia nudicaulis \\ Hypochoeris radicata \\ Hieracium castellanun \\ Filago lutescens
}

Figure 3. TWINSPAN dendrogram of samples $(B=$ burnt plot, $\mathrm{C}=$ cut plot, UT $=$ un-treated plot. The numbers after the letters indicate years after treatments). Preferential species in each cluster are indicated. 
in the last samplings. A trend to separate by time since the treatment is observed in these clusters of initial phases in each community on a third level of division; however, the separation is by the treatment in the clusters of final phases, with greater similarity between successive samplings in the same plot. The un-treated plot is more similar to the cut one in the Cistus laurifolius community and to the burnt plot in the Cistus ladanifer community.

\section{DISCUSSION}

The greater richness and cover of herbaceous species in the first few years after the disturbances stands out among the tendencies common to the four plots. This has also been mentioned by several authors 1,6 22, 24, 33]. On comparing the response to both disturbances a greater herbaceous abundance is observed (both in species number and cover) in the cut plots than in the burnt ones in the first years. This is the opposite of what other authors observed, such as Casal et al. [3], who found that fire produced floral changes with a peak in temporal diversity, but this did not occur after cutting because no pioneer species appeared. Naveh [22] also found more herbaceous species in regeneration after burning than after maquis clear-cut and attributes it to the fire destroying tannins and etheric oils in the litter and duff. Calvo et al. [2], also observed a proliferation of herbaceous species after disturbances in experimental heath plots and found no differences between cutting and burning either in terms of richness or cover.

Another common tendency as regards disturbance is that the recovery of both Cistus species is faster in the two burnt plots than in the cut ones, as is to be expected in species whose germination is stimulated by heat $[32,36]$. However, the differences are only appreciable in the first few years. Woody species are present since the first phases and there are no significant changes in richness in the successive years or when comparing treatments in the same community.

The trend to recover by autosuccession is observed in the greater similarity among the samplings from each community in the TWINSPAN. Samplings from each plot do not separate in the first phases, although the different speed of recovery for each treatment is showed in the cluster, which includes the first four samplings from the cut plot and only the first two from the burnt plot, and this is observed in the dendrogram for both communities. The recovery of the dominant species determines a general trend for differences between both experimental treatments to decrease in time. However, in the last phases there are greater similarity among the samples from each plot, due to lower species richness in the burnt plots than in the cut ones. This coincides with the results of most authors $[1,12,33$.

Thus, general tendencies of response to the disturbances are observed in the plots studied. They concur with those recorded for most Mediterranean-type ecosystems. Recovery occurs by autosuccession and the main changes are due to greater pioneer herbaceous species diversity in the initial years, associated with the lower dominance of woody species. Nevertheless, herbaceous proliferation is much lower after burning than cutting and this tendency is not at all common, even among similar ecosystems in the Mediterranean basin. Knowledge of the dynamic specific to each ecosystem is of vital importance to landscape management for its conservation, as it must not be forgotten that pioneer species associated with disturbances contribute to the extraordinary biodiversity of Mediterranean-type ecosystems to a great extent $[6,8$, 31].

\section{REFERENCES}

[1] Bond W.J., van Wilgen B.W., Fire and plants, Chapman \& Hall, London, 1996.

[2] Calvo L., Tárrega R., Luis E., The effect of human factors (cutting, burning and uprooting) on experimental heathland plots, Pirineos 140 (1992) 15-27.

[3] Casal M., Basanta M., García-Novo F., La regeneración de los montes incendiados en Galicia, Monografías de la Universidad de Santiago, 99, Univ. de Santiago, Santiago de Compostela, 1984.

[4] Casal M., Basanta M., González F., Montero R., Pereiras J., Puentes A., Post-fire dynamics in experimental plots of shrubland ecosystems in Galicia (NW Spain), in: Goldamer J.G., Jenkins M.J. (Eds.), Fire in ecosystem dynamics, SPB Academic Publishing, The Hague, 1990, pp. 33-42.

[5] Cochan W.G., The distribution of the largest of a set estimated variances as a fraction of their total, Ann. Eugen (Lond.) 11 (1941) 47-61.

[6] Cowling R.M., Rundel P.W., Lamont B.B., Arroyo M.K., Arianoutsou M., Plant diversity in Mediterranean climate regions, Tree 11 (9) (1996) 362-366.

[7] David, et al., The distribution of the ratio, in a single normal sample of range to standard deviation, Biometrika 41 (1954) 482-493.

[8] Davis G., Landscapes and biodiversity in Mediterranean-type ecosystems: the role of changing fire regimes, in: Moreno J.M. (Ed.), Large Forest Fires, Backhuys Publishers, Leiden, 1998, pp. 109-131.

[9] Dell B., Hopkins A.J.M., Lamont B.B. (Eds.), Resilience in Mediterranean-type Ecosystems, Dr. W. Junk Publ., Dordrecht, 1986. 
[10] Fernández-Santos B., Moreno-Marcos G., GómezGutierrez J.M., Regeneration of Cytisus multiflorus after fire, cutting and pulling out in the N-W of Spain, in: Bellan D., Bonin G., Emig C. (Eds.), Functioning and dynamics of natural and perturbed ecosystems, Technique et Documentation, Lavoisier, Intercept Ltd, Andover, 1995.

[11] Gill A.M., Groves R.H., Fire regimes in heathlands and their plant-ecological effects, in: Specht R.L. (Ed.), Heathlands and related shrublands of the world, Elsevier Scientific Publishing Company, Amsterdam, 1981, pp. 61-84.

[12] Hanes T.L., Succession after fire in the chaparral of southern California, Ecological Monographs 41 (1971) 27-52.

[13] Hill M.O., TWINSPAN - a FORTRAN program for arranging multivariate data in a ordered two-way table by classification of the individuals and attributes, Cornell University, Ithaca, N.Y., 1979.

[14] Kruger F.J., Plant community diversity and dynamics in relation to fire, in: Kruger F.J., Mitchell D.T., Jarvis J.U.M. (Eds.), Mediterranean type ecosystems. The role of nutrients, Springer-Verlag, Berlin, 1983, pp. 447-472.

[15] Legrand C., Regeneration of two Cistus species after prescribed burning, in: Trabaud L., Prodon R. (Eds.), Fire in Mediterranean ecosystems, ECSC-EEC-EAEC, Brussels, 1993, pp. 47-54.

[16] Luis-Calabuig E., Tárrega R., Alonso I., Seedlings regeneration of two Cistus species after experimental disturbances, Int. J. Wildland Fire 6 (1) (1996) 13-19.

[17] Luis-Calabuig L., Tárrega R., Calvo L., Marcos E., Valbuena L., History of landscape changes in northwest Spain according to land use and management, in: Trabaud L. (Ed.), Life and environment in the Mediterranean, WIT Press, Southampton, 2000, pp. 43-86.

[18] Mazzoleni S., Esposito A., Vegetative regrowth after fire and cutting of Mediterranean macchia species, in: Trabaud L., Prodon R. (Eds.), Fire in Mediterranean Ecosystems, ECSCEEC-EAEC, Brussels-Luxembourg, 1993, pp. 87-99.

[19] Ministerio de Agricultura, Mapas provinciales de suelos de León, Ministerio de Agricultura. Instituto Nacional de Investigaciones Agrarias, Departamento Nacional de Ecología, Madrid, 1973.

[20] Ministerio de Agricultura, Caracterización agriclimática de la provincia de León., Dirección General de la Producción Agraria, Madrid, 1980.

[21] Naveh Z., The evolutionary significance of fire in the Mediterranean Region, Vegetatio 29 (1975) 199-208.
[22] Naveh Z., Fire in the Mediterranean - a landscape ecological prespective, in: Goldamer J.G., Jenkins M.J. (Eds.), Fire in ecosystems dynamics, SPB Acedemic Publishing, The Hague, 1990, pp. 1-20.

[23] Naveh Z., Lieberman A.S., Landscape Ecology. Theory and Application, Springer-Verlag, New York, 1990.

[24] Ne'eman G., Goubitz S., Phenology of east Mediterranean vegetation, in: Trabaud L. (Ed.), Life and environment in the Mediterranean, WIT Press, Southampton, 2000, pp. 155-201.

[25] Ojeda F., Arroyo J., Marañón T., Biodiversity components and conservation of Mediterranean heathlands in Southern Spain, Biological Conservation 72 (1995) 61-72.

[26] Scheffe H., The analysis of variance, John Whiley \& Sons, INC. New York, 1959.

[27] Tárrega R., Luis E., Alonso I., Comparison of the regeneration after burning, cutting and ploughing in a Cistus ladanifer shrubland, Vegetatio 120 (1995) 59-67.

[28] Tárrega R., Luis E., Alonso I., Space-time heterogeneity in the recovery after prescribed burning and cutting in a Cistus laurifolius shrubland, Plant Ecology 129 (1997) 179-187.

[29] Thanos C.A., Marcou S., Post-fire regeneration in Pinus brutia forest ecosystems of Samos island (Greece): 6 years after, Acta Oecologica 12 (5) (1991) 633-642.

[30] Trabaud L., Fire and survival traits of plants, The role of fire in ecological systems, SPB Academic Publishing, The Hague, 1987, pp. 65-89.

[31] Trabaud L. (Ed.), Life and environment in the Mediterranean, WIT Press, Southampton, 2000.

[32] Trabaud L., Seeds: their soil bank and their role in post-fire recovery of ecosystems of the Mediterranean basin, in: Trabaud L. (Ed.), Life and environment in the Mediterranean, WIT Press, Southampton, 2000, pp. 229-259.

[33] Trabaud L., Lepart J., Diversity and stability in garrigue ecosystems after fire, Vegetatio 43 (1980) 49-57.

[34] Troumbis A.Y., Trabaud L., Some questions about flammability in fire ecology, Acta Oecologica Oecol. Plant. 10 (2) (1989) 167-175.

[35] Tutin, et al., Flora Europaea, Cambridge University Press, 1964-1980.

[36] Valbuena L., Tárrega R., Luis E., Influence of heat on seed germination of Cistus laurifolius and Cistus ladanifer, Int. J. Wildland Fire 2 (1) (1992) 15-20. 